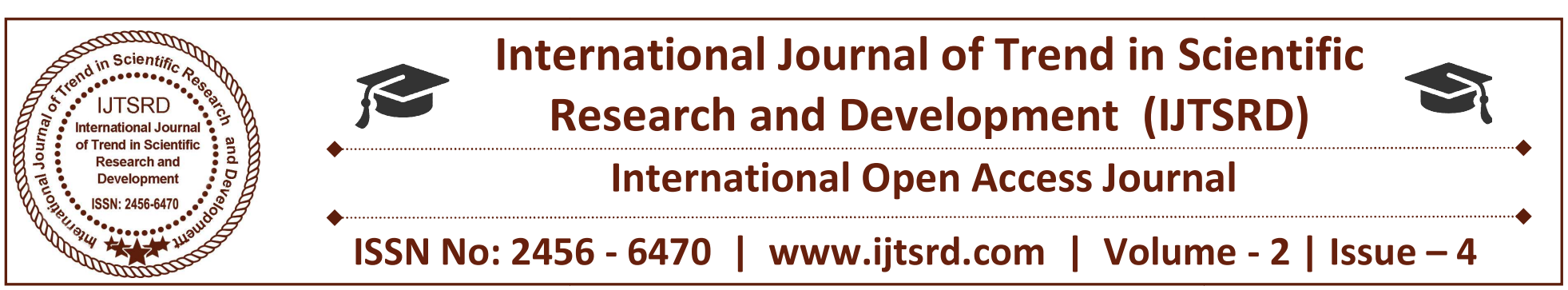

\title{
Impact of Globalization on The Quality of Life in India
}

\author{
Dinesh Adhikari \\ Assistant Professor, Government College, \\ Rhenock, East Sikkim, India
}

\section{GLOBALIZATION - INTRODUCTION}

Globalization is the social and moral change and development that is experienced practically in the daily life of a human being in all aspects of world trade, advanced communication, finance and economy, information technology and technology transfer, capitalism, health care, people and knowledge, labor and environment. The exports of India did not develop since 15 years of independence even though usage of tea, cotton, and jute are manufactured at a higher rate in India and also bestowed with its essential resources for production. These products were also a great demand in the whole world as they are daily essentials. World Trade Organisation(WTO) has estimated that India's contribution in the world trade accounts to $2.7 \%$ by 2015 which was only $1.2 \%$ in 2006 ("WTO $\mid$ Trade policy review - India 2002,"). Till reform " on liberalization was passed on 1991, India was solitary in the world market in its economy(Sahoo, 2014). 200 million dollars was the estimated annual turnover by FDI due to capital flow, deposits and borrowings of non-residential Indians, between 1985 and 1991 and the value was 63.08 billion in 2003. Most of the trading partners are from US, Japan, UK, EU(Srinivasan, 2002; Dr. Anil Kumar, 2015).

\section{ECONOMIC GROWTH DUE TO GLOBALIZATION AND ITS INFLUENCE ON EDUCATION}

Globalization in India facilitates the foreign companies to influence the economy of India indirectly by their investment in various fields that manage the economic activity and the requirement of the people in India on various products. The policy of 1991 about globalization in India has brought the upliftment of enjoying the standard and indulging India in becoming a developed country apart from the remark of a developing country. The economic reform called as LPG model, that quotes for Liberalization, Privatization, and Globalization along with Industrial and financial sectors by July 1991 contributed in making India's economy to increase and make it competitive among the other countries on the track in globalization and a great impact was observed after that reform. Also, the Multi-National Companies(MNCs) that collaborate with the Indian companies usually agrees for the joint venturing, employee exchange program, technology transfer, importing the lifestyle values and culture, liberty etc., and also overcoming the quantity limit for import, tariffs and duty taxes(Dhaval \& Rina, 2013).

FDI(Foreign Direct Investment) on integration with many Southeast Asian countries have emulsified the victory in economic rise making FDI, the profit makers. These investors provide increased wages to the employers and the inequality for the income of poverty line is greatly reduced in both the countries who are in the tie-up, increasing the living standards, productivity, and division of labor. The poverty line populace who earn 1 dollar or less has reduced from 1.5 billion to 1.1 billion from $1980 \mathrm{~s}-2001$ as per the reports of World Bank. This is why globalization is adopted for increasing the growth in the economy by foreign manufacturers and investors. The privatization of education in India made it comfortable for the foreign universities as a hub of investment and Indian students also earned their knowledge security by signing MOUs with both the countries. Education system became complex due to globalization and started earning conflicts in the name of the 
competitive world. The thirst and necessity to learn English Language booms the International schools to increase in number and also in re-constructing the curriculum to occupy their identity. This makes to launch inconvenient syllabus rather than practicing the needful education.

Twelfth Five Year Plan by the Government of India (2012-17) insists the school maintain the physical infrastructure, sufficient and talented teachers, text materials, academic support. At an early period, schools were approached by the parents only for education but now the ideology has changed in looking for every nook, for instance; water, mid-day meal practice, children friendly schools(Anand, 2015). Though these are really good in one aspect of globalization, there are aspects that are too nonessential for the education but the higher education and foreign studies have become much easier and approachable for the students.

\section{ENVIRONMENT AND THE ADULTERY- THE KINGMAKER OF GLOBALIZATION}

The pollution ratio demands the exploitation of the country on which investment is made for manufacturing. Increased $\mathrm{CO} 2$ emission is the greatest disadvantage and life-threatening factor in globalization. The restrictions and limitations that were ruled and followed in the society were broken and the gender getting mingled in various field, regarding job, education, socialism became evident normal. But minor populace exceeds their morality and they get engaged in live-in relationships, temporary commitments, sexual abusements, inculcating a thought in us that the motherly culture is wrongly uptaken due to globalization. Treatment of the guests and colleagues has become too jovial, enjoyable giving warm greetings, mercy love and treats are seen in India which hardly occurs in few countries and in early periods. The consideration for wealth and status has been a general attitude in everyone.

In the rice harvesting states of Tamil Nadu, West Bengal, and Kerala, $60 \%$ of employment in agricultural sector accounts for $30 \%$ of GNP where $78 \%$ of them are women and $63 \%$ are men. In Orissa, $105.4 \mathrm{hrs} / \mathrm{yr}$ of time is spent on shift cultivation by women. Any has to accept the truth that women can tackle the double burden that usually falls off on them to manage both household chores and their profession either it is in modern jobs like working in private sectors or in agriculture. The Self-Employed Women's Association (SEWA) with its co-operative bank containing 1,25,000 members have made the lives of even rural women mercy(Deb \& Sen, 2016).

\section{EFFECT OF THE CHANGE IN THE LIFESTYLE AND AGRICULTURAL SECTOR BY GLOBALIZATION}

A well-known fact in which sector, India highly enriched with quality and tradition is none other than the agricultural sector. MNC's entry into India has massively put down this sector as the youth icons look farming as a tag of illiteracy, nonprofit job and it makes them beat their ego. This situation directly proportionate to the slavery of these youngsters to MNCs instead of finding their own job and heritage. The term culture goes with the dealt of people's view on life and citizenship, values of heir own life along with the essence of their language and their occupancy region. This integral part of life has great respect and uniqueness in India because of its heritage, the friendly behavioral pattern of the citizens, vast religion followers, art, food, music, dialect and resources in India. This quality of both environment and people widely attracts the foreigners to settle down in India for business, tourism, adventure etc., Globalization directly impacts on India in westernization of cultures, for instance: the nuclear family/settlement became very common in the society, regarding the structure of the family instead of shadowing on the joint hoods and elderly. In contrast, marital values get depressed and obviously, all can visualize the divorce cases that are getting submitted in court.

\section{IT INDUSTRY IN INDIA}

The excessive impact of FDI from 1994 and foreign institutional investment (FII) made India, a strong platform for MNC'S (multinational corporations) which performs and manages the productive abilities of a company in more than one country, by providing an ambiance that makes the employers comfortable for the pay with norms and regulations being applied. It maintains a private governing authority to the candidates they recruit and with the Indian companies, they transfer their techno market that comes under the Corporates Social Responsibility(CSR). Most of these companies emerge from Europe, Britain, North America, Japan, Taiwan Brazil. But these corporate cause serious adverts to the developing countries most importantly India. They are the major causative agent 
for in improvisation of world trade. Almost 350 corporates control about $40 \%$ of the world trade in production and sales from their targeted developing countries like leather, clothing, electronics, and tobacco whereas accordingly the impact on the international exchange was studied about $1 / 4$ the of the total exchange value through MNCs. This immensely increases the Gross Domestic Product (GDP) of the investing country. The United Nations Conference on Trade and Development (UNCTAD) reported that stocks for the investor countries in had peaked to $\$ 1.4$ trillion at 2005. Foreign Direct Investment and China is the major player of the lead. MNC's not only invested in software and hardware industries but also in the plantation, fuel industries like petroleum and nonfuel minerals(Das, 2016).

\section{DEVELOPMENT OF INDIA DUE TO GLOBALIZATION}

Globalization has led the employment rate increase not only for men but also for the talented and interested women candidates who are the major workforce in the current scenario and they become self-confident and independent. India with its 1.21 billion population, and vast religion, caste, demands and the expectancy for longevity, cheaper and attracting products is the investment of the foreign companies and also the exports are done at efficient costs. By 1991, 64\% of the total profit of the nation was due to the agricultural outcome and $26.8 \%$ due to jute products. By 2001, the electronics and telecommunications have raised its usage on people and have improved the skills, quality, and production of labor team. India is the world's third largest country in product consumption. Within 10 years, cell phone usage hiked upon to $83.2 \%$ and also increased the production in software, hardware, and machinery. By early 2003, 19.2 million people were employed in 3.4 million small industrial units with $40 \%$ gross output in manufacturing, 35\% in exports. The World Trade Organization (WTO) constituted in 1995, made 11 countries including India to be the members of the to quantitate and demolish the restriction on imports and exports(Das, 2016).

\section{INTEGRATION ON CAPITALISM}

The pattern of Integration on capitalism and trade was stagnant for a very long time which boomed up only after1991 that can be tracked by the trade-GDP ratio that was lying between $12-15$ percent in the 1980s but elevated to 45 percent in 2010 . Even the
export-GDP ratio has changed its count from 6 percent (in 1991) to 20 percent (2010). If the reason for the growth of exports was analyzed, it depicts us clearly that it shot the change from $20 \%$ (in 1997) to $35 \%$ (2011) because of the constituents of exports and manufacturing sector.

(Veeramani, 2011,2012) have reported that the two shifts(capital intensity, India being the destiny) in the manufacturing sector is the cause of the export increase. Moreover, the capital intensity in India is cheaper than the developed countries and of course, the miscellaneous exports turned to $35 \%$ from $21 \%$ between 1998 and 2010. Even the appointments of skilled labors and restriction and tariffs for the capital goods were also found cheaper in India. Though this trade sector increased India's economy tremendously

the actual information is it had no difference in the standard of unskilled labors in getting employment or their economic status(Ghose, 2016).

\section{CHALLENGES IN THE MIDDLE-CLASS FAMILY}

Globalization has different effects especially the change in women in socio-economic life particularly in the cross-cultural change in the lifestyle of women. Their awareness inequality is speaking higher and higher. Globalization has helped a much of the international corporations becoming richer by earning billions of profits. The globalization has put down the food sector down and the underlying factor is the income is only $10 \%$ of the original income to be obtained and the more saddest part is that they own only $1 \%$ of even that pay as a result of too much exploitation due to globalized approach in all small fields.

Almost one-fifth of the total population in India live a middle-class life in their society and their living on income, status, power, consumption, experience, and expectancy are on a particular line(Zoya Hasan, 2013). Here comes the New Middle Class(NMC) populace that change after globalization from their usual way of a middle-class family. These NMC face challenges in human development, work pressures causing stress and health-related problems.

(Singh.J.P, 2004) says that the witness for the transformation from joint family values is changing tremendously in the urban scenario because of female-headed households and application of many cases in the court for divorce are also witnessed because of the conflict break. Women are decision 
makers even in their marital life as the effect of globalization have thought to know their own values and rights to speak up rather than going with the decision of the family. The lifestyle has changed completely where the children nowadays are leftover in a daycare center with the parents working in the nuclear family(Overgaard, 2010).

The combo of western culture in India and the capitalist activities by the tie-up companies which regularly sign up MOUs have dissolved family values and social control causing divorce, family violence, and misunderstandings and break down of family peace. Women have become more westernized in their form of dressing, even few women engage in smoking, dating. Satellite television, media has created immense tensions in the minds of an average middle-class family. The capitalism and economy in handshakes make the lives of these line of strategic people more complicated. Transnational Corporations (TNCs) consider the developing countries as their capitalization for manufacturing and marketing the products and medicines as the labor cost is very cheap and effective when compared to the other developing countries(Deb \& Sen, 2016).

\section{CONCLUSION}

Though the improvisation of the economy, standard and many more in India, it has deteriorated the Indian culture. India being a secular country, is too particular and was on the race of communism one side, but also a diffusing mindset that launched capitalism and globalization on the throne. Nowadays, one can possibly watch the out- directed culture in most of the families which we have or our ancestors have not experienced at all. Though the grace and need for money increased, telecommunication influenced us, the truth that has to be accepted of the people in the $21^{\text {st }}$ century of India is that all values that priorly was given to any kind of feelings, respect, honor, humanity or emotions were put down to the lower level. This is because the concept of individualismcommunitarianism is overwhelmed in all fields and also psychologically the independent lifestyle ratio is becoming a trending factor. Contrary to the popularism due to the IT industry, liberalization has re-structured even the actions of government. Most of the companies are just competing in shrinking the profit of each other and it depends completely on the usage of Information Technology by the investing country. Globalization gets succeeded only when the populace of a country expects a change and sustains and resists that change. One should be ready to change their prospects in every aspect and utilize each arriving opportunities to promote themselves in the society. We should support globalization for economic and other transformations without spoiling the ecosystem where we live in. It's our due responsibility to save agriculture and also to be conscious of our behavioral sense in the society that will not harm any lives or their mental health. Of course, this can be done only with mass populace involvement and be clear on self-attitude and esteem. The caste system that was followed in India and especially the heritage of Hinduism gets negatively affected which covers the holiness in the name of class and materialism than performing good deeds. The concept of karma has become losing its place in the hearts of the populace. This is because of the status of westernization and the dimension of viewing life on earth.

\section{REFERENCE}

1) Anand, M. (2015). GLOBALISATION AND INDIAN SCHOOL EDUCATION: IMPACT AND CHALLENGES. European Scientific Journal, ESJ, 11(10). Retrieved from http://eujournal.org/index.php/esj/article/view/572 7

2) Das, M. (2016). Globalization and its Positive Impact on Indian Economy (SSRN Scholarly Paper No. ID 2738054). Rochester, NY: Social Science Research Network. Retrieved from https://papers.ssrn.com/abstract $=2738054$

3) Deb, D. M., \& Sen, D. S. (2016). Globalisation and its impact on women in India: A review. International Journal of Applied Research, 2(7), 336-340.

4) Dhaval $P$ Dave \& Rina C. Dave (2013), "GLOBALISATION AND ITS IMPACT ON INDIAN ECONOMY", International Journal of Current Research, 5( 7),1628-1630.

5) Ghose, A. K. (2016). Globalization, Growth, and Employment in India. Indian Journal of Human Development, 10(2), 127-156. https://doi.org/10.1177/0973703016663536

6) Globalization and Its Effects on Indian Economy Geography Dr. Anil Kumar. (n.d.). 
International Journal of Trend in Scientific Research and Development (IJTSRD) ISSN: 2456-6470

7) Hasan. Z(2013)International Policy Centre for Inclusive Growth Poverty Practice, Bureau for Development Policy, Expanding Middle Classes and the Power Shift in India by, Jawaharlal Nehru University.

8) Overgaard, L. (2010). An analysis of Indian Culture in an Era of Globalisation, 51.

9) Sahoo, S. (2014). Globalization and Politics of the Poor in India. Journal of Asian and African Studies, 49(1), 3-15. https://doi.org/10.1177/0021909612471785.

10) Singh, J. P. (2004). The Contemporary Indian Family. In B. N. Adams \& J. Trost (Eds.), Handbook of World Families. CA: SAGE Publication, (129-166).

11) Srinivasan, T.N. (2002). "Economic Reforms and Global https://pdfs.semanticscholar.org/909d/ff9b00a27e de52d3e968e277a34da582caa4.pdf

12) VEERAMANI, C. (2012). Anatomy of India's Merchandise Export Growth, 1993-94 to 2010-11. Economic and Political Weekly, 47(1), 94-104.

13) Veeramani, C. (2012). The "miracle" still waiting to happen: Performance of India's manufactured exports in comparison to China (Mimeo). Mumbai: Indira Gandhi Institute of Development Research.

14) WTO | Trade policy review - India 2002. (n.d.). Retrieved May 21, 2018, from https://www.wto.org/english/tratop_e/tpr_e/tp195 e.htm

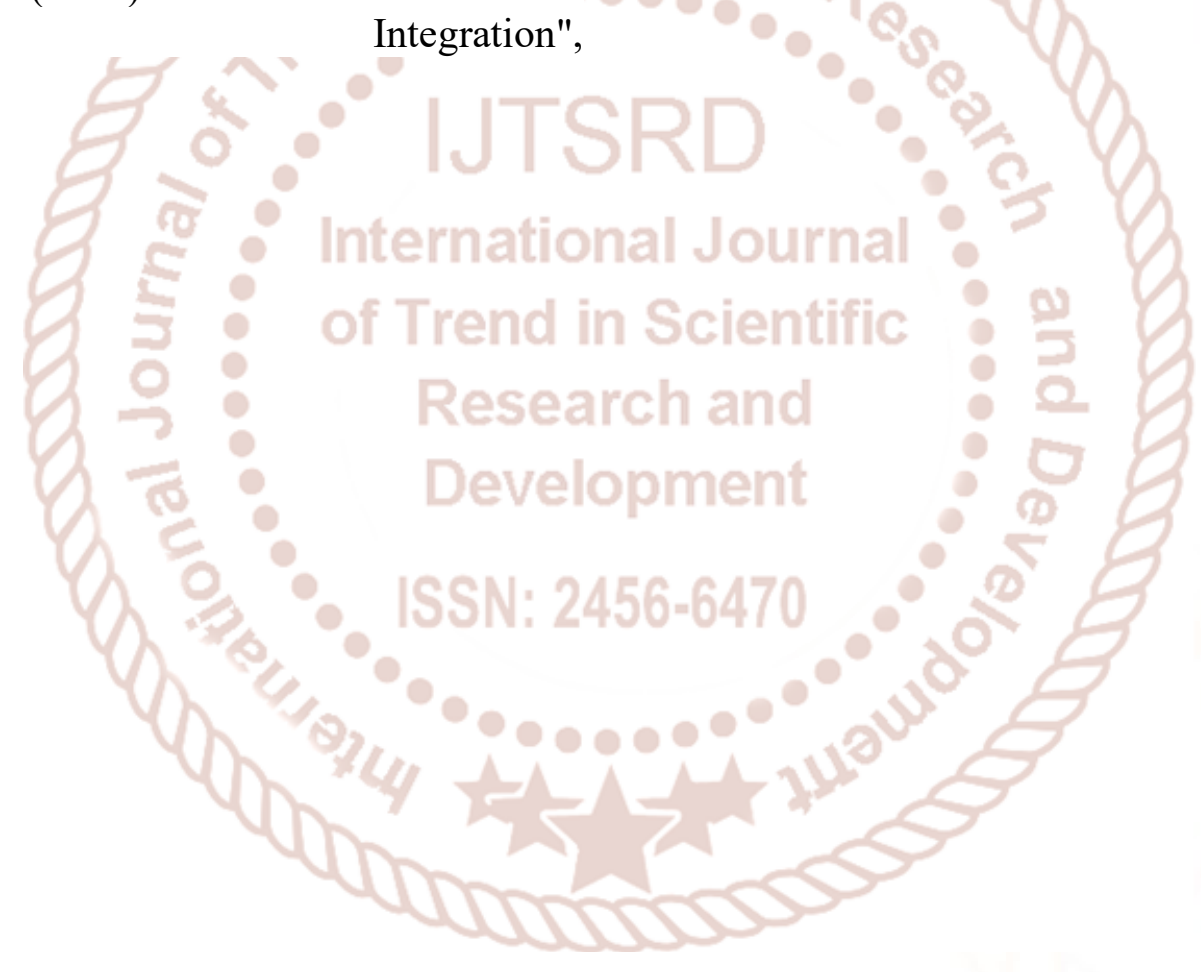

